\title{
Penyelesaian Persamaan Diferensial Hill Dengan Menggunakan Teori Floquet
}

\author{
Syarifah Inayati \\ Program Studi Matematika, Fakultas Matematika dan IImu Pengetahuan Alam, Universitas Ahmad \\ Dahlan, Jl. Prof. Dr. Soepomo, S.H., Janturan, Warungboto, Umbulharjo, Yogyakarta 55164, Indonesia \\ Korespondensi; Email: syarifah@math.uad.ac.id
}

\begin{abstract}
Abstrak
Analisis matematis dari berbagai macam masalah fisis banyak menghasilkan suatu perumusan yang melibatkan persamaan diferensial. Salah satu diantaranya yaitu jenis persamaan diferensial Hill yang merupakan suatu persamaan diferensial orde dua dengan koefisien berupa fungsi periodik. Bentuk persamaan diferensial tersebut dapat diselesaikan dengan menggunakan teori Floquet.
\end{abstract}

Kata Kunci: Persamaan diferensial; persamaan diferensial Hill; teori Floquet

\begin{abstract}
The mathematical analysis of a wide range of physical problems many produce a formulation involving differential equations. One of them is the type of differential equations Hill which is a second order differential equation with coefficients in the form of a periodic function. The shape of the differential equations can be solved using Floquet theory.
\end{abstract}

Keywords: Differential equations; differential equations Hill; Floquet theory

\section{Pendahuluan}

Pengembangan ilmu pengetahuan dan teknologi sering menggunakan penerapan matematika, diantaranya di bidang fisika, geometri, biologi, psikologi, kimia, dan ekonomi. Banyak masalah pada bidang-bidang tersebut yang model matematikanya menghasilkan suatu persamaan diferensial. Dari berbagai jenis persamaan diferensial yang dihasilkan, salah satu diantaranya adalah persamaan diferensial Hill, yaitu suatu persamaan diferensial orde dua dengan koefisien berupa fungsi periodik.

Persamaan diferensial Hill banyak digunakan terutama di bidang fisika. Banyak analisis matematis berbagai macam masalah fisis yang menghasilkan suatu perumusan menyangkut persamaan diferensial jenis ini. Masalah-masalah fisis tersebut diantaranya masalah getaran batang penggerak lokomotif, perambatan arus listrik dalam rangkaian penapis dan struktur listrik periodik yang lain, teori modulasi dalam telegrafi tanpa kawat, getaran harmonik sederhana, teori kestabilan bandul terbalikkan oleh gerak periodik titik tumpunya, teori kuantum logam, teori kemantapan penyelesaian beberapa persamaan diferensial nonlinear, dan sebagainya [3]. Hal ini menunjukkan bahwa betapa pentingnya persamaan ini dalam fisika matematis.

Suatu survai tentang sifat dasar analisis yang timbul dari penerapan-penerapan praktis menunjukkan bahwa analisis penyelesaian persamaan diferensial Hill dapat dibagi dalam dua kategori utama, yaitu: (1) Dalam kategori pertama, masalah-masalah yang menimbulkan persamaan diferensial Hill sebagai akibat dari pemisahan variabel suatu masalah nilai batas. Dalam hal ini penyelesaian yang sesuai dituntut merupakan fungsi periodik; (2) Dalam kategori kedua, masalah-masalah yang dapat dipandang sebagai masalah nilai awal yang didalamnya melibatkan persamaan jenis ini. Dalam hal ini penyelesaian-penyelesaian tidak terbatas pada penyelesaian periodik [3].

Dalam makalah ini akan dibahas suatu metode penyelesaian persamaan diferensial Hill dengan menggunakan teori Floquet. 


\section{Landasan Teori}

\section{Persamaan Diferensial}

Persamaan diferensial adalah persamaan yang memuat turunan atau diferensial dari satu atau lebih variabel terikat terhadap berturut-turut satu atau lebih variabel bebas. Secara umum persamaan diferensial orde yang lebih tinggi dapat dibawa ke bentuk sistem persamaan diferensial orde satu yang ekuivalen. Untuk membawa suatu persamaan diferensial orde ke- $n u^{(n)}=g\left(u, u^{\prime}, \ldots, u^{(n-1)}, t\right)$, dengan $g$ adalah fungsi $u, u^{\prime}, \ldots, u^{(n-1)}, t$ yang ditentukan ke bentuk sistem persamaan diferensial orde satu yang ekuivalen dapat dilakukan dengan mendefinisikan

$$
x_{1}=u, \quad x_{2}=u^{\prime}, \quad \ldots, \quad x_{n}=u^{(n-1)}
$$

Sehingga diperoleh suatu bentuk sistem persamaan diferensial orde satu yang ekuivalen:

$$
\begin{gathered}
x_{1}{ }^{\prime}=x_{2} \\
x_{2}{ }^{\prime}=x_{3} \\
\vdots \\
x_{n-1}{ }^{\prime}=x_{n} \\
x_{n}{ }^{\prime}=g\left(x_{1}, x_{2}, \ldots, x_{n}, t\right)
\end{gathered}
$$

Definisi 1. [2] Bentuk umum suatu sistem dari $n$ persamaan diferensial orde satu untuk $n$ fungsi $x_{1}(t), x_{2}(t), \ldots, x_{n}(t)$ yang tidak diketahui adalah

$$
x_{i}{ }^{\prime}=f_{i}\left(x_{1}, x_{2}, \ldots, x_{n}, t\right),(i=1,2, \ldots, n)
$$

dengan $f_{i}$ adalah fungsi dari $(n+1)$ variabel $x_{1}, x_{2}, \ldots, x_{n}$ dan $t$.

Dalam notasi vektor sistem persamaan diferensial orde satu pada Definisi 1 dapat ditulis dalam bentuk $\boldsymbol{x}^{\prime}=f(\boldsymbol{x}, t)$. Sistem persamaan diferensial ini dikatakan sistem persamaan diferensial linear jika $f(\boldsymbol{x}, t)$ adalah fungsi $\boldsymbol{x}$ yang linear, sehingga dapat dituliskan dalam bentuk $\boldsymbol{x}^{\prime}=A(t) \boldsymbol{x}+g(t)$ dengan $A(t)$ adalah matriks fungsi $t$ yang berukuran $n \times n$ dan $g(t)$ adalah vektor fungsi $t$. Jika $g(t)=0$ maka disebut sebagai sistem persamaan diferensial linear homogen orde satu.

Definisi 2. [2] Misalkan $x_{1}(t), x_{2}(t), \ldots, x_{n}(t)$ adalah $n$ penyelesaian dari sistem persamaan diferensial linear homogen $\boldsymbol{x}^{\prime}=A(t) \boldsymbol{x}$ dan $X(t)=\left[x_{1}(t), x_{2}(t), \ldots, x_{n}(t)\right]$ adalah matriks berukuran $n \times n$, penyelesaian dari:

$$
X^{\prime}=A
$$

Jika $x_{1}(t), x_{2}(t), \ldots, x_{n}(t)$ bebas linear, maka $X$ adalah fundamental matrix dan jika $X\left(t_{0}\right)=I_{n}, X(t)$ adalah principal fundamental matrix, sedangkan yang disebut Wronskian adalah determinan dari fundamental matrix tersebut,

$$
W(t)=d \quad X(t)
$$

Dari Definisi 2, jika $X(t)$ fundamental matrix yang merupakan penyelesaian dari $X^{\prime}=A$, maka $X(t) C$ juga merupakan penyelesaian, untuk matriks konstanta non-singular $C$. Apabila dimisalkan $Y(t)=X(t) C$, maka $Y(t)$ adalah matriks non-singular dan $Y^{\prime}=X^{\prime} C=A \quad C=A$. Dapat dilihat 
bahwa kolom-kolom dari matriks $Y$ adalah kombinasi linear dari kolom-kolom matriks $X$, dan penyelesaian

$$
x(t)=X(t) \mathbf{c}
$$

dengan $X(t)=\left[x_{1}(t), x_{2}(t), \ldots, x_{n}(t)\right]$ dan $\boldsymbol{c}$ adalah $n$ vektor dengan komponen $c_{1}, c_{2}, \ldots, c_{n}$.

Teorema 3. [2] Misakan $W(t)$ adalah Wronskian sebagaimana disebutkan pada Definisi 2. Apabila untuk suatu $t_{0} \in I, W\left(t_{0}\right)=0$, maka $x_{1}(t), x_{2}(t), \ldots, x_{n}(t)$ tak bebas linear dan $W(t)=0$ untuk semua $t \in I$. Sebaliknya, jika $W(t) \neq 0$ untuk suatu $t_{0} \in I$, maka $x_{1}(t), x_{2}(t), \ldots, x_{n}(t)$ bebas linear dan $W(t) \neq O$ untuk semua $t \in l$, dan

$$
W(t)=W\left(t_{0}\right) e \cdot\left\{\int_{t_{0}}^{t} t_{1}(s) d\right\}
$$

\section{Fungsi Periodik}

Definisi 4. [2] Suatu fungsi $f(t)$ dikatakan periodik apabila fungsi tersebut terdefinisi untuk setiap $t$ real, dan terdapat suatu bilangan positif sebarang $T$ sedemikian hingga:

$$
f(t+T)=f(t), \text { untuk semua } t
$$

Dari Definisi 4, fungsi $f(t)$ juga periodik dengan periode $k T$, untuk sebarang bilangan bulat $k$ $(k= \pm 1, \pm 2, \ldots)$, sehingga $f(t+k T)=f(t)$.

Lemma 5. [2] Misalkan $f(t)$ fungsi yang periodik dengan periode $T$ sehingga: $f(t+T)=f(t), \forall t$, maka

$$
\int_{t}^{t+T} f(s) d s=\int_{0}^{T} f(s) d s
$$

Bukti. Dimisalkan $\xi(t)=\int_{t}^{t+T} f(s) d s$, maka $\xi^{\prime}(t)=f(t+T)-f(t)=0$. Karena $f(t)$ merupakan fungsi yang periodik, maka $\xi(t)$ adalah konstanta yang sama dengan $\xi(0)$. Dimisalkan pula $\psi(t)=\int_{0}^{T} f(s) d s$ , dengan mengambil $t=0$, maka $\psi^{\prime}(t)=f(T)-f(0)=0$ Dengan demikian, dapat disimpulkan bahwa $\psi(t)$ juga berupa konstanta yang sama dengan $\xi(t)$, sehingga bukti lemma terpenuhi.

\section{Pembahasan Masalah}

\section{Persamaan Diferensial Hill}

Grimshaw [2] menyatakan bahwa persamaan diferensial Hill adalah suatu persamaan diferensial orde dua dengan koefisien berupa fungsi periodik, yang secara umum dapat dituliskan ke dalam bentuk

$$
u^{\prime \prime}+a(t) u=0, \quad a(t+T)=a(t) \quad(\text { untuk semua } t)
$$


dengan $u^{\prime \prime}=\frac{d^{2} u}{d t^{2}}$ dan suatu fungsi $u$ yang tidak diketahui serta turunan-turunannya, sedangkan $a(t)$ merupakan suatu fungsi periodik dengan periode pokok $T$.

\section{Teori Floquet}

Bentuk umum dari suatu sistem persamaan diferensial linear homogen dengan koefisien periodik diberikan sebagai berikut:

dengan,

$$
x^{\prime}=A(t)
$$

$$
A(t+T)=A(t) \text {, untuk semua } \mathrm{t}
$$

Matriks koefisien $A(t)$ pada persamaan (2) berukuran $n \times n$ dan diasumsikan merupakan matriks fungsi $t$ yang real dan kontinu, sehingga persamaan tersebut akan mempunyai penyelesaian.

Teorema di bawah ini akan menjadi dasar untuk pengembangan teori umum dari persamaan (2).

Teorema 6. [2] Misalkan $X(t)$ fundamental matrix untuk (2) sebagaimana didefinisikan pada Definisi 2, maka $X(t+T)$ juga merupakan fundamental matrix dan terdapat matriks konstanta non-singular $B$ sedemikian sehingga

dan juga,

$$
\text { B, } X(t+T)=X(t) B \text {, untuk semua } \mathrm{t}
$$

$$
\operatorname{det} B=e . \quad\left\{\int_{0}^{T} t_{1}(s) d\right\}
$$

Bukti: Karena $X(t)$ merupakan fundamental matrix, maka menurut Definisi $2 X^{\prime}(t)=A(t) X(t)$. Misalkan $Y(t)=X(t+T)$ maka dengan menggunakan (3) diperoleh $Y^{\prime}(t)=X^{\prime}(t+T)=A(t+T) X(t+T)$ $=A(t) Y(t)$. Sehingga dapat disimpulkan bahwa $Y(t)=X(t+T)$ juga merupakan fundamental matrix.

Dimisalkan pula $(X(t))^{-1}(Y(t))=Z(t)$ maka $Y(t)=X(t) Z(t)$ dan $Y^{\prime}(t)=X(t) Z^{\prime}(t)+X^{\prime}(t) Z(t)$, atau dapat dituliskan sebagai $A(t) Y(t)=X(t) Z^{\prime}(t)+A(t) X(t) Z(t)=X(t) Z^{\prime}(t)+A(t) Y(t)$, sehingga $X(t) Z^{\prime}(t)=0$, dan karena $\operatorname{det} X(t) \neq 0$ maka $Z^{\prime}(t)=0$. Dengan demikian $Z(t)$ adalah matriks konstanta, dan karena $\operatorname{det} Z(t)=\operatorname{det}\left\{[X(t)]^{-1}\right\} \operatorname{det}\{Y(t)\} \neq 0$, maka $Z(\mathrm{t})$ non-singular, sehingga dengan $Z(t)=B$ persamaan (4) terbukti.

Kemudian, untuk membuktikan (5), digunakan Teorema 3, yaitu $W(t)=W\left(t_{0}\right) \exp \left\{\int_{t_{0}}^{t} \operatorname{tr} A(s) d s\right\}$ dengan $W(t)=\operatorname{det} X(t) \quad$ adalah Wronskian dari $X(t)$. Oleh karena itu $W(t+T)=W\left(t_{0}\right) \exp \left\{\int_{t_{0}}^{t} \operatorname{tr} A(s) d s+\int_{t}^{t+T} t r A(s) d s\right\}$. Dari persamaan (4) diperoleh $X(t+T)=X(t) B$ maka $\operatorname{det}(X(t+T))=\operatorname{det}(X(t) B) . \quad$ Sehingga diperoleh $W(t+T)=\operatorname{det} X(t) \operatorname{det} B=W(t) \operatorname{det}(B) . \quad$ Dari tiga persamaan di atas dan dengan memperhatikan Lemma 5 maka akan diperoleh $\operatorname{det} B=\exp \left\{\int_{t}^{t+T} \operatorname{tr} A(s) d s\right\}=\exp \left\{\int_{0}^{T} \operatorname{tr} A(s) d s\right\}$, sehingga persamaan (5) terbukti.

Karena persamaan (4) berlaku untuk semua $t$, maka matriks konstanta $B$ dapat dinyatakan dalam fundamental matrix dengan mengambil $t=0$,

$$
B=X^{-1}(0) X(T)
$$


Persamaan di atas akan digunakan untuk memilih $X(t)$ sebagai principal fundamental matrix, sehingga $X(O)=\operatorname{In}$ dan $B=X(T)$.

Definisi 7. [2] Misalkan $\rho_{1}, \rho_{2}, \ldots, \rho_{n}$ adalah nilai eigen dari matriks B (pada persamaan (4) atau (6)) disebut juga sebagai pengganda karakteristik (characteristic multipliers) untuk (2). Eksponen karakteristik (characteristic exponents) $\mu_{1}, \mu_{2}, \ldots ., \mu_{n}$ didefinisikan oleh:

$$
\rho_{1}=e^{\mu_{1} T}, \rho_{2}=e^{\mu_{2} T}, \ldots, \rho_{n}=e^{\mu_{n} T}
$$

Eksponen karakteristik pada definisi 7 disebut juga eksponen Floquet (Floquet exponents). Eksponen karakteristik $\mu_{1}, \mu_{2}, \ldots, \mu_{n}$ ini tidak tunggal, sehingga $\mu_{i}$ dapat digantikan dengan $\mu_{i}+\frac{2 \pi i k}{T}$, $(i=1,2, \ldots, n)$ untuk sebarang bilangan bulat $k= \pm 1, \pm 2, \ldots$ dengan tanpa mengubah definisi persamaan (7).

Jika dipilih $X(t)$ sebagai principal fundamental matrix, sehingga $B=X(T)$, maka pengganda karakteristik adalah nilai eigen dari $X(T)$, dengan $X(O)=I_{n}$.

Teorema 8. (Teorema Floquet) [2] Misalkan $\rho$ adalah pengganda karakteristik untuk (2) dan misalkan pula $\mu$ adalah eksponen karakteristik yang bersesuaian, sehingga $\rho=e^{\mu T}$, maka terdapat $x(t)$ penyelesaian dari (2) sedemikian hingga:

$$
x(t+T)=\rho x(t), \text { untuk semua } t
$$

Dan terdapat $p(t)$ fungsi periodik, yaitu $p(t+T)=p(t)$ untuk semua $t$, sedemikian hingga:

$$
x(t)=e^{\mu} p(t), \text { untuk semua } t
$$

Bukti. Misalkan $\boldsymbol{b}$ adalah vektor eigen dari matriks $B$ yang bersesuaian dengan nilai eigen $\rho$ sehingga $B \boldsymbol{b}=\rho \boldsymbol{b}$, maka diambil $x(t)=X(t) \boldsymbol{b}$, dan $x(t)$ merupakan penyelesaian dari (2).

Dari definisi tersebut dan dengan menggunakan (4) diperoleh:

$$
x(t+T)=X(t+T) \boldsymbol{b}=X(t) B \boldsymbol{b}=X(t) \rho \boldsymbol{b}=\rho
$$

sehingga persamaan (8) terbukti.

Kemudian diambil, $p(t)=x(t) e^{-\mu t}$ dan dengan menggunakan persamaan (8) diperoleh:

$$
p(t+T)=x(t+T) e^{-\mu(t+T)}=\rho x(t) e^{-\mu t} e^{-\mu T}=e^{\mu T} x(t) e^{-\mu t} e^{-\mu T}=x(t) e^{-\mu t}=p(t)
$$

Sehingga telah ditunjukkan bahwa untuk $p(t)$ suatu fungsi periodik (dengan $p(t+T)=p(t), \forall t)$ berlaku $p(t)=x(t) e^{-\mu t}$ atau $x(t)=e^{\mu t} p(t)$, dengan demikian persamaan (9) terbukti.

Perhatikan, apabila $\mu$ diganti dengan $\mu+\frac{2 \pi i k}{T}$, untuk sebarang bilangan bulat $k$ $(k= \pm 1, \pm 2, \ldots)$, maka persamaan (9) menjadi

$$
x(t)=e^{\mu t}\left\{p(t) \exp \frac{2 \pi i k}{T} t\right\}
$$


pada persamaan di atas, dapat dilihat bahwa $\left\{p(t) \exp \frac{2 \pi i k}{T} t\right\}$ merupakan fungsi $t$ yang periodik dengan periode $T$, sehingga bentuk persamaan (9) tidak berubah dan $\mu$ yang tidak tunggal ini tidak berdampak pada teori yang dikembangkan sekarang.

Bentuk penyelesaian umum dari (2) diperoleh dengan memisalkan bahwa $\boldsymbol{b}_{\mathbf{1}}, \boldsymbol{b}_{\mathbf{2}}, \ldots, \boldsymbol{b}_{\boldsymbol{n}}$ adalah $n$ vektor eigen yang bebas linear dari $B$ yang bersesuaian dengan nilai eigen $\rho_{1}, \rho_{2}, \ldots, \rho_{n}$. Menurut Teorema 8 , akan terdapat $n$ penyelesaian yang bebas linear untuk (2), yang diberikan oleh

$$
x_{i}(t)=e^{\mu, t} p_{i}(t)(i=1,2, \ldots, n)
$$

dengan $p_{,}(t)$ untuk $i=1,2, \ldots, n$ adalah fungsi yang periodik dengan periode $T$.

Kemudian dimisalkan

$$
P_{0}(t)=\left[p_{1}(t), p_{2}(t), \ldots, p_{n}(t)\right]
$$

Maka $P_{d}(t)$ adalah matriks fungsi $t$ berukuran $n \times n$ yang non-singular dan periodik, maka $P_{d}(t+T)=P_{d}(t)$ untuk semua $t$. Berikutnya dibentuk fundamental matrix untuk (2) dari $n$ penyelesaian (10) yang bebas linear, sehingga

$$
X_{0}(t)=\left[x_{1}(t), x_{2}(t), \ldots, x_{n}(t)\right]=P_{0}(t) Y_{0}(t)
$$

dengan $Y_{0}(t)=\operatorname{diag}\left[e^{\mu_{1} t}, e^{\mu_{2} t}, \ldots, e^{\mu_{n} t}\right]$

Pada persamaan (12) di atas $Y d t$ memenuhi

$$
Y_{0}^{\prime}=D_{0} Y_{0} \text { dengan } \quad D_{0}=\operatorname{diag}\left[\mu_{1}, \mu_{2}, \ldots, \mu_{n}\right]
$$

yang merupakan matriks persamaan diferensial dengan koefisien konstan.

Bentuk umum penyelesaian untuk (2) adalah $X_{0}(t) C$, dengan $C$ sebarang matriks konstanta. Dari persamaan (9) yang merupakan penyelesaian (2) dapat dilihat bahwa (2) mempunyai penyelesaian yang periodik dengan periode $T$ jika eksponen karakteristik $\mu \equiv 0$ (modulo $\frac{2 \pi i}{T}$ ) atau bersesuaian dengan pengganda karakteristik $\rho=1$. Selain itu terdapat pula penyelesaian yang periodik dengan periode $m T(m=2,3, \ldots)$ untuk $\mu \equiv \frac{2 \pi i}{m T}$ (modulo $\frac{2 \pi i}{T}$ ) atau bersesuaian dengan pengganda karakteristik $\rho=\exp \frac{2 \pi i}{m}$ sedemikian hingga $\rho^{m}=1$.

Penyelesaian seperti pada persamaan (9) di atas, akan diperoleh bila pengganda karakteristik $\rho$ dan eksponen karakteristik $\mu$ bernilai real. Apabila $\rho$ dan $\mu$ bernilai kompleks, persamaan (9) tetap berlaku dengan $X(t)$ juga bernilai kompleks.

Pertama, apabila $\rho$ bernilai real dan negatif $(\rho<0)$, sehingga $\mu$ bernilai kompleks, untuk memperoleh fundamental matrix yang bernilai real, diambil

$$
\mu=\frac{i_{1}}{T}+v, \text { dimana } e^{v}=-\rho
$$

maka $v$ bernilai real dan persamaan (9) menjadi 


$$
x(t)=e^{\left(\frac{i}{T}+v\right) t} p(t)=e^{\left(\frac{i:}{T}\right) t} e^{v} p(t)=e^{v} q(t) \text { dengan } q(t)=e \cdot\left(\frac{i_{1}}{T} t\right) \cdot p(t)
$$

Dari persamaan terakhir, dapat dilihat bahwa karena $\exp \left(\frac{i \pi}{T} t\right)$ mempunyai periode 2 dan $p(t)$ mempunyai periode $T$, maka $q(t)$ periodik dengan periode $2 T$, yaitu $q(t+2 T)=q(t)$ untuk semua $t$. Dengan mengambil $q(t)$ bernilai real, maka didapat fundamental matrix bernilai real. Untuk setiap pengganda karakteristik $\rho_{i}<0 ; \quad v_{i}$ ditentukan dengan persamaan (14) dan $q_{i}(t)$ ditentukan dengan persamaan (15). Sedangkan kolom $p_{\lambda}(t)$ dalam $\left.P d t\right)$ pada persamaan (11) diganti dengan $q_{\lambda}(t)$, sehingga menjadi

$$
Q_{0}(t)=\left[q_{1}(t), q_{2}(t), \ldots, q_{n}(t)\right]
$$

Unsur-unsur $e^{\mu_{i} t}$ dalam $Y_{d}(t)$ diganti dengan $e^{v_{i} t}$ dan unsur-unsur $\mu_{i}$ dalam $D_{0}$ diganti dengan $v_{i}$.

Kedua, apabila $\rho$ bernilai kompleks maka $\rho$ dan $\bar{\rho}$ merupakan pasangan konjugat-kompleks dari nilai eigen $B$ sedangkan $\mu$ dan $\bar{\mu}$ keduanya sebagai eksponen karakteristik. Berikut ini diberikan gambaran agar didapat penyelesaian bernilai real untuk (2), yaitu dengan memandang kasus $n=2$. Dengan demikian, $B$ adalah matriks berukuran $2 \times 2$ dengan nilai eigen $\rho$ dan $\bar{\rho}$, sedangkan eksponen karakteristik yang bersesuaian adalah $\mu$ dan $\bar{\mu}$. Dimisalkan $\mu=v+i \sigma$, dimana $|\rho|=e^{v T}$ dan $\arg (\rho)=\sigma T$. Menurut Teorema 8, maka akan dihasilkan pasangan konjugat-kompleks penyelesaian-penyelesaian yang diberikan oleh (9), dengan memisalkan $p(t)=q(t)+i r(t)$ dengan $q(t)$ dan $r(t)$ adalah fungsi $t$ bernilai real yang periodik dengan periode $T$, persamaan (9) menjadi

$$
x(t)=e^{(v+i \sigma) t}\{q(t)+i r(t)\}
$$

Sehingga bagian real dan bagian imajiner dari persamaan di atas menghasilkan pasangan penyelesaian-penyelesaian bebas linear yang bernilai real untuk (2), yang diberikan oleh:

$$
\begin{aligned}
& \operatorname{Re}\left\{e^{\mu t} p(t)\right\}=e^{v t}\{\cos \sigma t \cdot q(t)-\sin \sigma t \cdot r(t)\} ; \\
& \operatorname{Im}\left\{e^{\mu t} p(t)\right\}=e^{v t}\{\sin \sigma t \cdot q(t)+\cos \sigma t \cdot r(t)\}
\end{aligned}
$$

Selanjutnya matriks $P_{O}(t)$ pada persamaan (11) diganti dengan matriks periodik:

$$
Q_{0}(t)=[q(t), r(t)]
$$

Dan fundamental matrix $X_{0}(t)$ untuk (2) dibentuk dari dua penyelesaian yang bebas linear yang ditentukan oleh (16), sehingga persamaan (12) menjadi:

$$
X_{0}(t)=Q_{0}(t) Y_{0}(t)
$$

dengan $Y_{0}(t)=e^{v t}\left[\begin{array}{cc}\cos \sigma t & \sin \sigma t \\ -\sin \sigma t & \cos \sigma t\end{array}\right]$

dan $Y d(t)$ memenuhi persamaan:

$$
Y_{0}^{\prime}=F_{0} Y_{0} \text {, dengan } F_{0}=\left[\begin{array}{cc}
v & \sigma \\
-\sigma & v
\end{array}\right]
$$

Dengan demikian apabila $A$ merupakan matriks berukuran $n \times n$, fundamental matrix $X d(t)$ diberikan oleh persamaan (12), dengan kolom-kolom $P_{d}(t)$ adalah fungsi $t$ periodik dengan periode $T$ (atau 
mempunyai periode $2 T$ bila pengganda karakteristik $\rho$ bernilai real dan negatif). Matriks $Y_{0}(t)$ adalah matriks yang hanya mempunyai unsur tak nol pada diagonal utama dengan bentuk $e^{\mu t}$, yang merupakan pengganda karakteristik $\rho$. Submatriks-submatriks berukuran $2 \times 2$ dengan (18) terpusat pada diagonal utama, bersesuaian dengan setiap pasangan konjugat-kompleks dari pengganda karakteristik. Selanjutnya Do pada persamaan (13) adalah matriks yang hanya mempunyai unsur tak nol pada unsur-unsur diagonalnya yang berupa $\mu$ atau submatriks-submatriks berukuran $2 \times 2$ dengan bentuk $F_{0}$ pada persamaan (19) terpusat pada diagonal utama.

Selanjutnya, dalam membahas penyelesaian persamaan diferensial Hill dengan menggunakan teori Floquet, penulis merujuk pada metode yang dikembangkan oleh Grimshaw [2] dan Simakhina [4].

\section{Penyelesaian Persamaan Diferensial Hill Menggunakan Teori Floquet}

Dipandang persamaan diferensial Hill:

$$
u^{\prime \prime}+a(t) u=0
$$

dengan $a(t+T)=a(t)$, untuk semua $t$.

Penyelesaian persamaan diferensial Hill di atas dapat dicari dengan menerapkan teori Floquet, yang dapat dilakukan dengan langkah-langkah sebagai berikut:

a. Menentukan sistem persamaan diferensial orde satu yang ekuivalen dengan persamaan diferensial Hill.

Untuk membawa persamaan (20) yang merupakan persamaan diferensial orde dua untuk fungsi $u(t)$ ke bentuk sistem persamaan diferensial orde satu yang ekuivalen sesuai dengan Definisi 1, terlebih dahulu ditentukan

$$
x_{1}=u \quad x_{2}=u^{\prime}
$$

maka persamaan (20) ekuivalen dengan sistem persamaan diferensial orde satu berikut ini

$$
\begin{gathered}
x_{1}{ }^{\prime}=x_{2} \\
x_{2}{ }^{\prime}=-a(t) x_{1}
\end{gathered}
$$

dalam bentuk matriks dapat ditulis

$$
x^{\prime}=\left[\begin{array}{l}
x_{1}{ }^{\prime} \\
x_{2}{ }^{\prime}
\end{array}\right] ; \quad A(t)=\left[\begin{array}{cc}
0 & 1 \\
-a(t) & 0
\end{array}\right] ; \quad x=\left[\begin{array}{l}
x_{1} \\
x_{2}
\end{array}\right]
$$

matriks $A(t)$ di atas dapat dilihat bahwa $\operatorname{tr} A(t)=0$.

b. Mencari fundamental matrix $X(t)$ dan matriks konstanta non-singular $B$ sedemikian hingga $B=$ $X^{-1}(0) X(T)$, dengan $X(0)=I_{2}$.

Bentuk fundamental matrix $X(t)$ untuk (22), sedemikian hingga $X(0)=12$, adalah

$$
X(t)=\left[\begin{array}{ll}
u_{1}(t) & u_{2}(t) \\
u_{1}{ }^{\prime}(t) & u_{2}{ }^{\prime}(t)
\end{array}\right]
$$

dengan $u_{1}(t)$ dan $u_{2}(t)$ adalah penyelesaian (20) yang bebas linear, sedemikian sehingga

$$
\begin{array}{ll}
u_{1}(0)=1, & u_{2}(0)=0, \\
u_{1}{ }^{\prime}(0)=0, & u_{2}{ }^{\prime}(0)=1
\end{array}
$$


Matriks $B$ yang diberikan oleh persamaan (6), dengan $X(0)=/ 2$ adalah

$$
B=\left[\begin{array}{ll}
u_{1}(T) & u_{2}(T) \\
u_{1}{ }^{\prime}(T) & u_{2}^{\prime}(T)
\end{array}\right]
$$

karena $\operatorname{tr} A(t)=0$, maka persamaan (5) menghasilkan

$$
\operatorname{det} B=\exp \left\{\int_{0}^{T} \operatorname{tr} A(t) d t\right\}=\exp \left\{\int_{0}^{T} 0 d t\right\}=\exp \{0\}=1
$$

Karena $\operatorname{det} B=1$, ini menunjukkan bahwa Wronskian dari (23) yang merupakan determinan dari fundamental matrix $X(t)$ adalah

$$
\left.u_{1} u_{2}{ }^{\prime}-u_{2} u_{1}{ }^{\prime}=1 \text {, (untuk semua } t\right) \text {. }
$$

c. Menentukan $\rho_{1,2}$ pengganda karakteristik dan $\mu_{1,2}$ eksponen karakteristik dari matriks $B$, dengan $\rho_{1,2}$ merupakan fungsi dari suatu parameter $\emptyset$.

Pengganda karakteristik $\rho$ yang merupakan nilai eigen $B=X(T)$ diperoleh dari

$$
\operatorname{det}\left(\rho I_{2}-B\right)=0
$$

Perhatikan, $\quad \rho I_{2}-B=\left[\begin{array}{cc}\rho-u_{1} & -u_{2} \\ -u_{1}{ }^{\prime} & \rho-u_{2}{ }^{\prime}\end{array}\right]$

karena $\operatorname{det}\left(\rho I_{2}-B\right)=0$, maka $\rho^{2}-\left(u_{2}{ }^{\prime}+u_{1}\right) \rho+1=0$ atau $\rho^{2}-2 \cdot \frac{1}{2}\left(u_{2}{ }^{\prime}+u_{1}\right) \rho+1=0$ sehingga

$$
\rho^{2}-2 \phi \rho+1=0, \text { dengan } \phi=\frac{1}{2}\left\{u_{1}(T)+u_{2}{ }^{\prime}(T)\right\}
$$

jadi nilai eigen $\rho_{1,2}$ adalah fungsi dari parameter $\phi$ dan diberikan oleh

$$
\rho_{1,2}=\phi \pm \sqrt{\phi^{2}-1}
$$

Persamaan di atas mengakibatkan

$$
\rho_{1} \rho_{2}=1, \rho_{1}+\rho_{2}=2 \phi
$$

Dari definisi eksponen karakteristik $\phi$ dengan $\rho_{1,2}=e^{\mu_{1,2} T}$ dan (29) mengakibatkan

$$
\mu_{1}+\mu_{2}=0 \cosh \mu_{1} T=\phi
$$

d. Menentukan penyelesaian umum persamaan diferensial Hill berdasarkan sifat dari $\rho_{1,2}$ atau $\mu_{1,2}$ dalam $\varnothing$. 
Parameter $\phi$ pada (27) akan digunakan untuk mengelompokkan sifat dari $\rho_{1,2}$ atau $\mu_{1,2}$ dalam $\phi$.

(i) $\phi>1$ : Pada kasus ini, dengan memperhatikan (28), maka $\rho_{1,2}$ keduanya real dan positif, dan $\rho_{1}>1>\rho_{2}>0$. Akibatnya $\mu_{1}$ pada (30) adalah real dan positif, sedangkan $\mu_{2}\left(=-\mu_{1}\right)$ adalah real dan negatif. Dari pembahasan tentang teori Floquet (lihat persamaan 12) dapat disimpulkan bahwa penyelesaian umum dari persamaan (20) adalah

$$
u=c_{1} e^{\mu_{1} t} p_{1}(t)+c_{2} e^{-\mu_{1} t} p_{2}(t)
$$

dengan $p_{1,2}(t+T)=p_{1,2}(t), \quad($ untuk semua $t)$.

Secara umum, $|u| \rightarrow \infty$ bila $t \rightarrow \infty$ dan dapat dilihat bahwa tidak terdapat penyelesaian periodik.

(ii) $\phi<-1$ : Pada kasus ini, dengan memperhatikan (28) maka $\rho_{1,2}$ keduanya real dan negatif dan $\rho_{2}<-1<\rho_{1}<0$. Akibatnya dengan mengubah tanda pada persamaan (14), diambil

$$
\mu_{1}=\frac{i \pi}{T}-\gamma, \cosh \gamma T=-\phi
$$

Untuk kasus ini dengan memperhatikan (15) maka penyelesaian umum untuk (20) adalah:

$$
u=c_{1} e^{-\gamma t} q_{1}(t)+c_{2} e^{\gamma t} q_{2}(t)
$$

dengan $q_{1,2}(t+2 T)=q_{1,2}(t)$, (untuk semua $\left.t\right)$.

Secara umum, $|u| \rightarrow \infty$ bila $t \rightarrow \infty$ dan dapat dilihat bahwa tidak terdapat penyelesaian periodik.

(iii) $-1<\phi<1$ : Pada kasus ini, $\rho_{1,2}$ keduanya bernilai kompleks dengan besaran satu $\left(\left|\rho_{1,2}\right|=1\right)$ , dan diperoleh

$$
\rho_{1,2}=\exp ( \pm i \sigma T), \mu_{1}=i \sigma
$$

dengan $\cos \sigma T=\phi \quad(0 \leq \sigma T \leq \pi)$

Penyelesaian umum untuk persamaan (20) dengan menggunakan (16) adalah

$$
u=c_{1} \operatorname{Re}\left\{e^{i \sigma t} p(t)\right\}+c_{2} \operatorname{Im}\left\{e^{i \sigma t} p(t)\right\}
$$

dengan $p(t+T)=p(t)$, (untuk semua $t$ ).

Fungsi $p(t)$ merupakan fungsi periodik yang bernilai kompleks. Persamaan (20) akan mempunyai penyelesaian periodik dengan periode $m T$, bilamana $\sigma T=\frac{2 \pi}{m}$ untuk $m=3,4, \ldots$

(iv) $\phi=1$ : Kasus ini merupakan batas antara kasus (i) dan (iii) hanya terdapat pengganda karakteristik tunggal, $\rho_{1}=1$ dan eksponen karakteristik yang tunggal, $\mu_{1}=0$. Ini dapat dianggap sebagai limit $\mu_{1} \rightarrow 0$ pada kasus (I), atau $\sigma \rightarrow 0$ pada kasus (iii).

Penyelesaian umumnya adalah: 


$$
u=c_{1} p_{1}(t)+c_{2}\left\{k t p_{1}(t)+p_{2}(t)\right\}
$$

dengan $p_{1,2}(t+T)=p_{1,2}(t)$, (untuk semua $\left.t\right)$.

Konstanta $k$ pada persamaan di atas boleh sama dengan nol. Dengan memilih $c_{2}=0$, akan terdapat suatu penyelesaian dengan periode $T$.

(v) $\phi=-1$ : Kasus ini merupakan batas antara kasus (ii) dan (iii), juga hanya terdapat pengganda karakteristik tunggal, $\rho_{1}=-1$ dan eksponen karakteristik tunggal, $\mu_{1}=\frac{i \pi}{T}$. Ini dapat dianggap sebagai limit $\gamma \rightarrow 0$ pada kasus (ii), atau $\sigma \rightarrow \frac{\pi}{T}$ pada kasus (iii).

Penyelesaian umumnya adalah:

$$
u=c_{1} q_{1}(t)+c_{2}\left\{k t q_{1}(t)+q_{2}(t)\right\}
$$

dengan $q_{1,2}(t+2 T)=q_{1,2}(t)$, (untuk semua $\left.t\right)$.

Demikian pula pada penyelesaian tersebut $k$ juga merupakan konstanta yang boleh sama dengan nol. Dengan memilih $c_{2}=O$ akan terdapat penyelesaian dengan periode $2 T$.

\section{Contoh Soal dan Penyelesaian}

Salah satu bentuk persamaan diferensial Hill adalah:

$$
u^{\prime \prime}+\left\{\omega^{2}+\epsilon(t)\right\} u=0
$$

Dengan $b(t+T)=b(t) \quad$ (untuk semua $t)$.

Untuk $\epsilon=0$ persamaan di atas menggambarkan osilasi harmonik sederhana dengan frekuensi $\omega$ dan periode $T_{0}=\frac{2 \pi}{\omega}$. Tentukan penyelesaian umum dari persamaan tersebut pada saat $\epsilon=0$ dimana menunjukkan keadaan terjadinya resonansi parametrik!

(Petunjuk. Resonansi parametrik terjadi pada batas antara perilaku yang stabil dan tidak stabil. Hal ini ditandai dengan keberadaan solusi periodik dengan periode $T$ atau $2 T$.)

Penyelesaian Masalah. Karena ingin dicari penyelesaian pada saat $\epsilon=0$, sehingga persamaan (38) dapat ditulis menjadi

$$
u^{\prime \prime}+\omega^{2} u=0
$$

dengan frekuensi $\omega$ dan periode $T_{0}=\frac{2 \pi}{\omega}$. (39).

Pertama, akan ditentukan sistem persamaan diferensial orde satu yang ekuivalen dengan persamaan

Ambil $x_{1}=u$ dan $x_{2}=u^{\prime}$, maka sistem persamaan diferensial orde satu yang ekuivalen dengan (38) adalah

$$
\begin{gathered}
x_{1}{ }^{\prime}=x_{2} \\
x_{2}{ }^{\prime}=-\omega^{2} x_{1}
\end{gathered}
$$

Dalam bentuk matriks dapat ditulis sebagai

$$
\begin{aligned}
x^{\prime} & =A(t) x \\
\Leftrightarrow \quad\left[\begin{array}{l}
x_{1}^{\prime} \\
x_{2}^{\prime}
\end{array}\right] & =\left[\begin{array}{cc}
0 & 1 \\
-\omega^{2} & 0
\end{array}\right]\left[\begin{array}{l}
x_{1} \\
x_{2}
\end{array}\right]
\end{aligned}
$$


Karena $A(t)=\left[\begin{array}{cc}0 & 1 \\ -\omega^{2} & 0\end{array}\right]$, maka diperoleh $t_{1} A(t)=0$. Maka dengan menggunakan persamaan (5) diperoleh:

$$
\operatorname{det} B=\exp \left\{\int_{0}^{T} \operatorname{tr} A(t) d t\right\}=\exp \left\{\int_{0}^{T} 0 d t\right\}=\exp \{0\}=1
$$

Kedua, akan dicari fundamental matrix $X(t)$ dan matriks konstanta non-singular $B$ sedemikian hingga $B=X^{-1}(0) X(T)$, dengan $X(0)=I_{2}$.

Sebelumnya dapat dicari penyelesaian umum dari persamaan diferensial (39) adalah

$$
u=c_{1} \cos \omega t+c_{2} \sin \omega t
$$

dengan $c_{1}$ dan $c_{2}$ konstanta sebarang, yang merupakan fungsi periodik dengan periode $T_{0}=\frac{2 \pi}{\omega}$.

Perhatikan, diketahui bahwa $X(t)=\left[\begin{array}{ll}u_{1}(t) & u_{2}(t) \\ u_{1}^{\prime}(t) & u_{2}^{\prime}(t)\end{array}\right]$, dengan $u_{1}$ dan $u_{2}$ adalah penyelesaian bebas linear yang memenuhi syarat awal

$$
u_{1}(0)=1 ; u_{1}{ }^{\prime}(0)=0 \text { dan } u_{2}(0)=0 ; u_{2}{ }^{\prime}(0)=1
$$

dari penyelesaian umum (40) diperoleh bahwa penyelesaian bebas linear dari (39) yaitu fungsi $u_{1}(t)=c_{1} \cos \omega t$ dan $u_{2}(t)=c_{2} \sin \omega t$. Untuk $u_{1}(t)=c_{1} \cos \omega t$ terhadap kondisi awal yang pertama $u_{1}(0)=1 \rightarrow 1=c_{1} \cos 0 \rightarrow c_{1}=1$ dan terhadap kondisi awal yang kedua $u_{1}^{\prime}(0)=0 \rightarrow 0=-c_{1} \omega \sin 0$, karena $\sin 0=0$, maka persamaan tersebut berlaku untuk sembarang harga $c_{1}$. Jadi, solusi khusus yang memenuhi kedua kondisi awal itu adalah $u_{1}(t)=c_{1} \cos \omega t$. Sedangkan, untuk $u_{2}(t)=c_{2} \sin \omega t$ terhadap kondisi awal yang pertama $u_{2}(0)=0 \rightarrow 0=c_{2} \sin 0$ karena $\sin 0=0$, maka persamaan tersebut berlaku untuk sembarang harga $c_{2}$ dan terhadap kondisi awal yang kedua $u_{2}^{\prime}(0)=1 \rightarrow$ $1=c_{2} \omega \cos 0 \rightarrow c_{2}=\frac{1}{\omega}$. Jadi, solusi khusus yang memenuhi kedua kondisi awal adalah $u_{2}(t)=\frac{1}{\omega} \sin \omega t$. Sehingga diperoleh, $u_{1}(t)=\cos \omega t$ dan $u_{2}(t)=\frac{1}{\omega} \sin \omega t$.

Maka, $X(t)=\left[\begin{array}{ccc}\cos \omega t & \frac{1}{\omega} s_{i} & \omega t \\ -\omega_{s i} & \omega t & \cos \omega t\end{array}\right]$

Matriks $B$ yang ditentukan oleh $B=X^{-1}(0) X(T)$ dengan $X(0)=/ 2$ adalah

$$
B=\left[\begin{array}{ccc}
\cos \omega T & \frac{1}{\omega} s_{i} & \omega T \\
-\omega s_{i} & \omega T & \cos \omega T
\end{array}\right]
$$

Ketiga, akan ditentukan $\rho_{1,2}$ pengganda karakteristik dan $\mu_{1,2}$ eksponen karakteristik dari matriks $B$, dengan $\rho_{1,2}$ merupakan fungsi dari suatu parameter $\phi$.

Perhatikan, 


$$
\rho-B=\left[\begin{array}{ccc}
\rho-\cos \omega_{T} & -\frac{1}{\omega} s & \omega_{T} \\
\omega_{S i} & \omega_{T} & \rho-\cos \omega_{T}
\end{array}\right]
$$

Pengganda karakteristik $\rho$ yang merupakan nilai eigen $B$ diperoleh $\operatorname{dari} \operatorname{det}(\rho-B)=0$ maka $\rho^{2}-2 \rho \cos \omega+1=0$ atau dapat ditulis

$$
\rho^{2}-2 \phi \rho+1=0 \text { dengan } \phi=\cos \omega T
$$

Jadi nilai eigen $\rho_{1,2}$ adalah fungsi dari parameter $\phi$ dan diberikan oleh

$$
\rho_{1,2}=\phi \pm \sqrt{\phi^{2}-1}
$$

dengan $\phi=\cos \omega T$, sehingga $\rho_{1,2}=\cos \omega T \pm i \sin \omega T$

Akibatnya, $\quad \rho_{1} \rho_{2}=1$,

$$
\rho_{1}+\rho_{2}=2 \cos \omega T
$$

$$
\mu_{1}+\mu_{2}=0
$$

$$
\cosh \mu_{1} T=\cos \omega T
$$

Keempat, akan ditentukan penyelesaian umum persamaan (39) berdasarkan sifat dari $\rho_{1,2}$ atau $\mu_{1,2}$ dalam $\phi$.

Dari langkah ketiga, telah diperoleh harga $\phi=\cos \omega T$, yang akan digunakan untuk mengelompokkan sifat dari $\rho_{1,2}$ atau $\mu_{1,2}$. Dalam kasus ini, karena resonansi parametrik terjadi pada batas antara perilaku yang stabil dan tidak stabil yang ditandai dengan keberadaan solusi periodik dengan periode $T$ atau $2 T$, maka akan diselidiki suatu penyelesaian umum untuk persamaan (39) pada periode $\mathrm{T}$ dan $2 \mathrm{~T}$.

(i) Untuk $\phi=1$, ini berarti

$\cos \omega T=1 \Leftrightarrow \cos \omega T=\cos 0 \Leftrightarrow \omega T=0+2 k \Leftrightarrow \omega T=2 k \quad$ atau $T=k T_{0}$ dan karena $\phi=1$, akibatnya diperoleh $\rho_{1,2}=1$ dan $\mu_{1,2}=0$ Karena $\rho$ dan $\mu$ bernilai real, dari teori umum pada teori Floquet (perhatikan persamaan (12)) dapat ditunjukkan bahwa $X_{0}(t)=P_{0}(t) Y_{0}(t)$ maka

$$
\begin{aligned}
X_{0}(t) & =\left[p_{1}(t), p_{2}(t)\right] \cdot \operatorname{diag}\left[e^{\mu_{1} t}, e^{\mu_{2} t}\right] \\
& =\left[\begin{array}{ccc}
\cos \omega t & \frac{1}{\omega} s_{i} & \omega t \\
-\omega s_{i} & \omega t & \cos \omega t
\end{array}\right]\left[\begin{array}{cc}
e^{0 t} & 0 \\
0 & e^{0 t}
\end{array}\right]
\end{aligned}
$$

Jadi penyelesaian umumnya adalah

$$
\begin{gathered}
u=c_{1} p_{1}(t)+c_{2}\left\{k t p_{1}(t)+p_{2}(t)\right\} \\
\Leftrightarrow u=c_{1} \cos \omega t+c_{2}\left\{k t \cos \omega t+\frac{1}{\omega} \sin \omega t\right\}
\end{gathered}
$$

Konstanta $k$ pada persamaan di atas boleh sama dengan nol. Dengan memilih $c_{2}=0$, akan terdapat suatu penyelesaian dengan periode $T$.

(ii) Untuk $\phi=-1$, ini berarti

$\cos \omega T=-1 \Leftrightarrow \cos \omega T=\cos \pi \Leftrightarrow \omega T=\pi+2 k \Leftrightarrow \omega T=(2 k+1) \pi \quad$ atau $2 T=$ $(2 k+1) T_{0}$ dan karena $\phi=-1$, akibatnya $\rho_{1,2}=-1$ dan $\mu_{1,2}=\frac{i \pi}{T}$ 
Perhatikan, $\rho$ real dan negatif sedemikian sehingga $\mu$ bernilai kompleks, dari teori umum pada teori Floquet (perhatikan persamaan (14)) dapat ditunjukkan bahwa

$$
\begin{aligned}
& X_{0}(t)=Q_{0}(t) Y_{0}(t) \\
& X_{0}(t)=\left[q_{1}(t), q_{2}(t)\right] \cdot \operatorname{diag}\left[e^{v_{1} t}, e^{v_{2} t}\right] \\
& =\left[\begin{array}{cc}
\exp \left(\frac{i \pi t}{T}\right) \cos \omega t & \exp \left(\frac{i \pi t}{T}\right) \frac{1}{\omega} \sin \omega t \\
-\omega \exp \left(\frac{i \pi t}{T}\right) \sin \omega t & \exp \left(\frac{i \pi t}{T}\right) \frac{1}{\omega} \cos \omega t
\end{array}\right]\left[\begin{array}{cc}
e^{0 t} & 0 \\
0 & e^{0 t}
\end{array}\right]
\end{aligned}
$$

Jadi penyelesaian umumnya adalah

$$
\begin{gathered}
u=c_{1} q_{1}(t)+c_{2}\left\{k t q_{1}(t)+q_{2}(t)\right\} \\
\Leftrightarrow u=c_{1} \exp \left(\frac{i \pi t}{T}\right) \cos \omega t+c_{2}\left\{k t \exp \left(\frac{i \pi t}{T}\right) \cos \omega t+\exp \left(\frac{i \pi t}{T}\right) \frac{1}{\omega} \sin \omega t\right\}
\end{gathered}
$$

Demikian pula pada penyelesaian tersebut $k$ juga merupakan konstanta yang boleh sama dengan nol. Dengan memilih $c_{2}=O$ akan terdapat penyelesaian dengan periode $2 T$.

\section{Kesimpulan}

Persamaan diferensial Hill adalah suatu persamaan diferensial orde dua dengan koefisien berupa fungsi periodik. Bentuk persamaan diferensial tersebut dapat diselesaikan dengan menggunakan teori Floquet. Metode penyelesaian tersebut dilakukan dengan mengubah persamaan diferensial Hill yang merupakan persamaan diferensial linear homogen orde dua ke bentuk sistem persamaan diferensial orde satu yang ekuivalen, kemudian dari sistem persamaan diferensial tersebut dapat ditentukan penyelesaian persamaan diferensial Hill dengan menggunakan teori Floquet.

\section{Referensi}

[1] Boyce, W. E. and Richard, C. D., 1986, Elementary Differential Equations and Boundary Value Problem (Fourth Edition), New York: John Wiley \& Sons.

[2] Grimshaw, R., 1990, Nonlinear Ordinary Differential Equations. London: Blackwell Scientific Publications.

[3] Pipes, Louis. A \& Harvill, R. L., 1991, Matematika Terapan untuk Para Insinyur dan Fisikawan (jilid 2), Terjemahan Muslim, Sumartono Prawirosusanto, \& Peter Soedojo, Yogyakarta: Gajah Mada University Press.

[4] Simakhina, S.V., 2003, Stability Analysis of Hills Equation, Thesis pada Department of Mathematics, Statistics and Computer Science at the University of Illinois at Chicago: diterbitkan. 